\title{
Les mots et les actes
}

Allumer le feu, baratter. Question de texte et d'ensemble technique

\section{Marie-Claude Mahias}

\section{(2) OpenEdition}

\section{Journals}

Édition électronique

URL : https://journals.openedition.org/tc/773

DOI : $10.4000 /$ tc. 773

ISSN : 1952-420X

Éditeur

Éditions de l'EHESS

\section{Édition imprimée}

Date de publication : 1 octobre 1990

ISSN : 0248-6016

\section{Référence électronique}

Marie-Claude Mahias, «Les mots et les actes », Techniques \& Culture [En ligne], 14 | 1990, mis en ligne le 16 janvier 2006, consulté le 29 septembre 2022. URL : http://journals.openedition.org/tc/773 ; DOI : https://doi.org/10.4000/tc.773

Ce document a été généré automatiquement le 29 septembre 2022.

Tous droits réservés 


\section{Les mots et les actes}

Allumer le feu, baratter. Question de texte et d'ensemble technique

Marie-Claude Mahias 